\title{
EVALUASI KINERJA BUS PATAS ANTAR KOTA DALAM PROPINSI TRAYEK PROBOLINGGO-MALANG
}

\author{
Andi Syaiful A. ${ }^{1)}$, Anik Sepnawati ${ }^{2)}$ \\ 1,2) Jurusan Teknik Sipil Universitas Muhammadiyah Malang \\ Alamat korespondensi : Jl. Raya Tlogomas 246 Malang 65144 \\ andiama199@yahoo.co.id
}

\begin{abstract}
"Bus Patas" is one means of urban transport that is used by people who want to Probolinggo poor or vice versa, its existence is a potential to be served because of the activities that are often carried out by people such as trade, education, social, cultural and others. As a means of transportation bus patas not be separated from the issues affecting the performance of services. Hiatus seat, passenger numbers increased on busy days, the sharpening competition among the fleet on the same route, is an indication of where conditions require patas bus transportation performance evaluation. There should be a study to determine the level of performance of freight, transport and analysis needs to strike a balance between demand and supply at the moment.

This refers to the evaluation study on the performance parameters issued by the Directorate General of Land Transportation.

The evaluation results known load factor average for these Probolinggo-Malang is 0.78 , the speed of the average travel routes Probolinggo-Malang $45.66 \mathrm{~km} / \mathrm{h}$, headway route Probolinggo-Malang 30.30 minutes, travel time average for these Probolinggo-Malang at 1:31 $\mathrm{min} / \mathrm{km}$ and the value of the frequency for Probolinggo-Malang route for $1.98 \mathrm{veh} /$ hour. And the results of the analysis of the balance between supply and demand obtained the required fleet needs today is 40 fleet.
\end{abstract}

Keywords: public transport, service indicator, total fleet

\section{PENDAHULUAN}

Angkutan Umum Penumpang (AUP) trayek Probolinggo - Malang sebagai bagian dari sistem transportasi adalah salah satu kebutuhan masyarakat, dan merupakan bagian yang tidak dapat dipisahkan dari kebutuhan kota pada umumnya. Namun keberadaan angkutan umum penumpang jika tidak ditangani dengan baik dan benar akan menjadi masalah bagi kehidupan.

Rute Probolinggo - Malang merupakan rute yang dilayani oleh beberapa moda transportasi salah satunya adalah Bus Patas. Dimana bus patas adalah sarana transportasi yang juga banyak digunakan oleh masyarakat Probolinggo yang ingin ke Malang maupun sebaliknya.

\section{TUJUAN STUDI}

Adapun tujuan dari evaluasi ini adalah untuk mengetahui tingkat kinerja Bus Patas trayek Probolinggo-Malang, dan Untuk mengetahui (supply) armada yang sesuai dengan kebutuhan (demand) pada saat ini.

\section{TINJAUAN PUSTAKA}

\section{Frekuensi}

Menurut Morlok (1978) frekuensi adalah jumlah kendaraan yang lewat per satuan waktu. Frekuensi dapat dirumuskan sebagai berikut:

$$
\mathrm{F}=1 / \mathrm{H}
$$

Dimana $: \mathrm{F}=$ Frekuensi (kend/menit)

$$
\mathrm{H}=\text { Headway (menit) }
$$

\section{Headway}

Menurut Nasution (2004), Headway adalah selisih waktu keberangkatan antara dua pelayanan angkutan umum pada satu titik tertentu atau selisih waktu kedatangan antara kendaraan sebelumnya dengan kendaraan berikutnya.

$$
\mathrm{H}=\frac{60}{Q / j a m}
$$

$$
\begin{aligned}
& \text { Dimana }: \mathrm{Q} / \mathrm{jam}= \text { jumlah kendaraan dalam } \\
& \text { satu jam } \\
& \mathrm{H} \quad=\text { headway dalam menit }
\end{aligned}
$$




\section{Load Factor (Faktor Muat)}

Load factor didefinisikan sebagai rasio total penumpang kendaraan dengan jumlah tempat duduk yang tersedia. Load factor (LF) merupakan perbandingan antara kapasitas terjual dan kapasitas yang tersedia untuk satu perjalanan yang bisa dinyatakan dalam persen (\%) (Abubakar: 1995).

$$
\begin{aligned}
\mathrm{LF}= & \frac{J P}{C} \times 100 \\
\text { Dimana: } & \\
\mathrm{LF}= & \text { Load Factor }(\%) \\
\mathrm{JP}= & \text { Banyaknya penumpang yang } \\
& \text { diangkut sepanjang satu lintasan } \\
& \text { sekali jalan } \\
\mathrm{C}= & \begin{array}{l}
\text { Daya tampung kendaraan atau } \\
\text { banyaknya tempat duduk }
\end{array}
\end{aligned}
$$

\section{Waktu Tunggu}

Menurut Dirjen Perhubungan Darat (1996) menyatakan bahwa waktu tunggu adalah waktu yang diperlukan bagi calon penumpang untuk menunggu kendaraan yang melewati satu jalan.

Menurut Abubakar (1995) waktu tunggu dinyatakan dengan rumus :

$$
\text { Waktu tunggu }=0,5 \times \text { Headway (menit) }
$$

\section{Kecepatan Perjalanan}

Menurut Morlok (1978), kecepatan perjalanan kecepatan perjalanan dari awal rute ke titik akhir rute dan di rumuskan dengan :

$$
\mathrm{V}=\frac{S}{t}
$$

Dimana : V = Kecepatan rata-rata

$\mathrm{S}=$ Jarak tempuh

$\mathrm{t}=$ Waktu tempuh rata-rata

\section{Waktu Perjalanan}

Menurut Dodiet \& Romzan (2003) menyatakan bahwa waktu perjalanan adalah waktu perjalanan angkutan umum pada setiap rute, dan dirumuskan dengan:

$$
\begin{aligned}
& \text { Waktu Perjalanan }= \\
& \frac{\text { Panjang Rute }}{\text { Kecepatanrata }- \text { rata }} \times 60 \text { menit }
\end{aligned}
$$

\section{METODOLOGI PENELITIAN}

Adapun tahapan studi yang pada saat evaluasi kinerja bus Patas antar kota ini, dapat dilihat pada diagram alir yang terdapat pada Gambar 1.

\section{HASIL DAN PEMBAHASAN}

Dari hasil evaluasi menunjukkan bahwa kinerja angkutan umum penumpang bus patas trayek Probolinggo-Malang dan sebaliknya dilapangan secara analisis telah memenuhi ketentuan dari Dinas Perhubungan Darat. Namun tidak semua kriteria dapat mencapai kinerja maksimum yang telah ditetapkan.

Hasil perhitungan load factor didapat rata-rata pada jam sibuk untuk bus patas rute Probolinggo-Malang adalah sebesar 0.90 (90\%) dan rute Malang-Probolinggo sebesar 0.90 (90\%). Load factor diluar jam sibuk didapat 0.64 (64\%) untuk rute ProbolinggoMalang dan 0.66 (66\%) untuk rute MalangProbolinggo. Sehingga didapat load factor rata-rata untuk rute Probolinggo-Malang sebesar 0.78 (78\%) dan untuk rute MalangProbolinggo sebesar 0.74 (74\%).

Untuk kecepatan perjalanan rute Probolinggo-Malang adalah $45.66 \mathrm{Km} / \mathrm{jam}$ sedangkan rute Malang-Probolinggo sebesar $45.22 \mathrm{Km} / \mathrm{jam}$, nilai headway rata-rata diperoleh 30.30 menit untuk rute Probolinggo-Malang dan 30.15 menit untuk rute Malang-Probolinggo, waktu perjalanan rata-rata rute Probolinggo-Malang adalah 1.31 menit $/ \mathrm{km}$ sedangkan rute MalangProbolinggo sebesar 1.32 menit $/ \mathrm{km}$, untuk frekuensi armada bus patas didapat 1.98 kend/jam untuk rute Probolinggo-Malang dan $1.99 \mathrm{kend} / \mathrm{jam}$ untuk rute MalangProbolinggo.

\section{Evaluasi Keseimbangan Supply dan Demand}

Evaluasi keseimbangan supply dan demand untuk angkutan umum penumpang didasarkan pada kondisi permintaan dan penyediaan (demand and supply), sehingga dapat diketahui apakah dengan adanya perbaikan akan menambah tingkat pelayanan dari angkutan umum penumpang tersebut. Evaluasi perbaikan terhadap keseimbangan supply dan demand armada angkutan bus patas ini dilakukan sebagai berikut: 


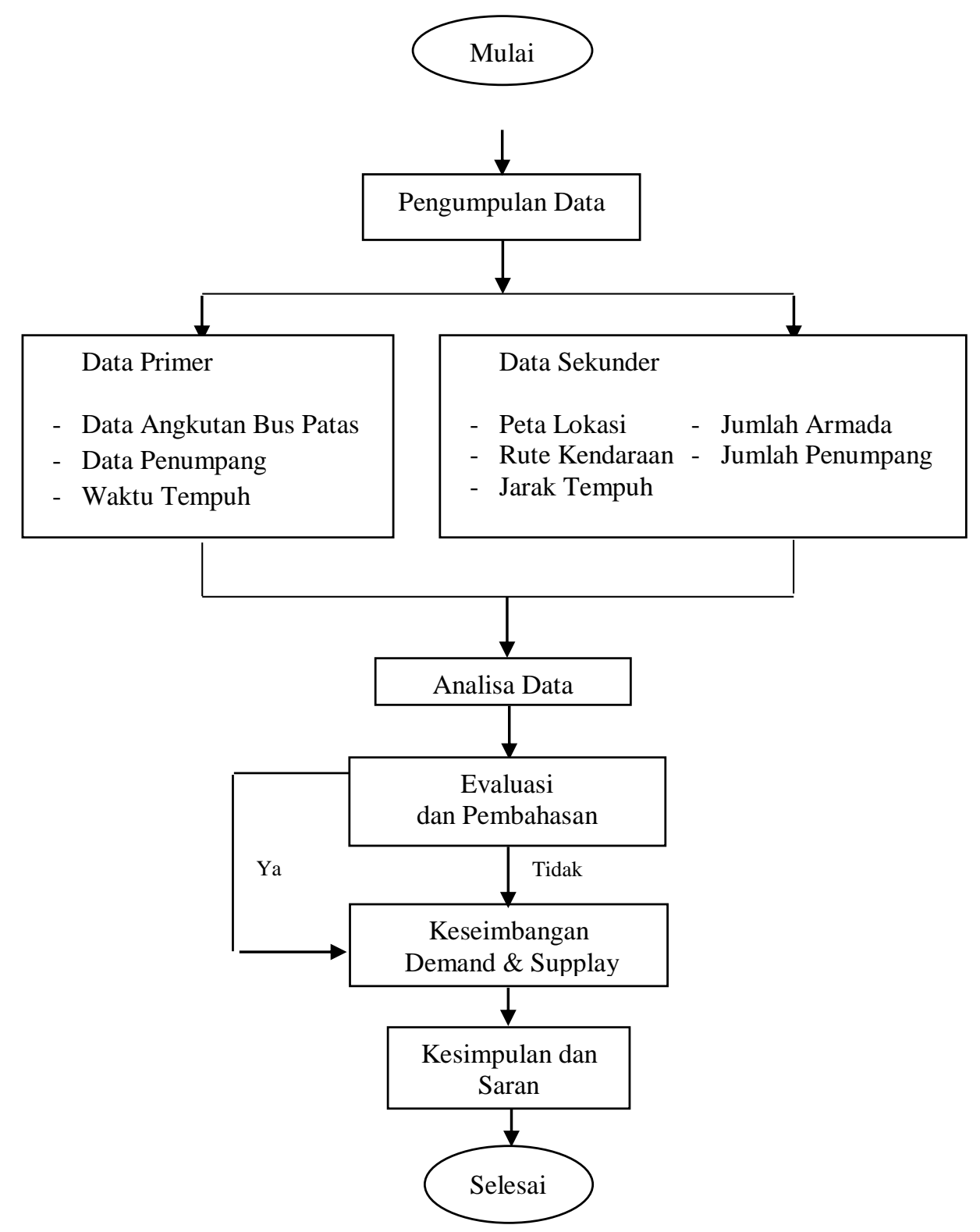

Gambar 1. Diagram Alir Penelitian

Ketersediaan Jumlah Armada berdasarkan Armada yang Beroperasi

Perhitungan ketersediaan jumlah armada yang disesuaikan dengan armada yang beroperasi saat ini adalah sebagai berikut:

Diketahui :

- Jumlah armada yang beroperasi : 23 bus/hari

- Hari operasi setiap armada : 4 hari/mggu

- Jumlah Rit : 2 rit/hari

- Penentuan ketersediaan jumlah armada :
Jumlah rit/hari

$=$ jumlah armada yang beroperasi $\mathrm{x}$ jumlah rit/hari

$=23$ bus $\mathrm{x} 2 \mathrm{rit} / \mathrm{hari}$

$=46 \mathrm{rit} / \mathrm{hari}=322 \mathrm{rit} / \mathrm{mggu}$

Maka jumlah bus yang operasi setiap minggu

$$
\begin{aligned}
& =\frac{322 \mathrm{rit} / \mathrm{mggu}}{4 \mathrm{hari} / \mathrm{mggu}} \\
& =80,5 \mathrm{rit} / \mathrm{hari} \\
& =\frac{80,5 \mathrm{rit} / \mathrm{hari}}{2 \mathrm{rit} / \mathrm{hari}}=40,25 \approx 40 \mathrm{bus}
\end{aligned}
$$




\section{Rotasi Armada}

Selain peningkatan pelayanan angkutan dengan mengevaluasi kebutuhan armada yang sesuai, perlu juga dipertimbangkan konsep pengaturan dalam pengoperasian armada. Untuk mengetahui operasi armada tiap hari, maka dilakukan simulasi dengan cara cobacoba dalam pengoperasian armada secara berkala dan disesuaikan dengan jumlah armada yang beroperasi. Hasil simulasi tersebut menunjukkan pengoperasian armada tiap hari per minggu untuk masing-masing armada yang telah disesuaikan dengan jumlah armada hasil evaluasi.

Untuk pengaturan dan pengoperasian armada secara berkala ini diserahkan sepenuhnya kepada Koperasi Perusahaan Otobus selaku koordinator/paguyuban angkutan pada trayek tersebut.

\section{Tinjauan terhadapArmada Berijin Trayek}

Analisa jumlah armada berdasarkan armada yang berijin trayek untuk angkutan bus patas trayek Probolinggo-Malang adalah sebagai berikut:

Diketahui :

Jumlah armada total : 63 armada

Hari operasi $\quad: 4$ hari/mggu

Jumlah Rit $\quad: 2$ rit/hari

Penentuan ketersediaan jumlah armada :

Jumlah bus yang dibutuhkan

$=$ jumlah armada yang berijin $\mathrm{x}$ hari operasi

$=63$ armada bus $\mathrm{x} 4$ hari operasi $/ \mathrm{mggu}$

$=252 \mathrm{bus} / \mathrm{mggu} \approx 36 \mathrm{bus} / \mathrm{hari}$

Dari hasil perhitungan evaluasi keseimbangan supply dan demand didapat kebutuhan armada yang diperlukan trayek Probolinggo-Malang adalah 40 armada.

\section{KESIMPULAN DAN SARAN}

\section{Kesimpulan}

Dari hasil evaluasi dan analisa kinerja armada bus patas angkutan kota dalam propinsi (AKDP) rute Probolinggo-Malang, diperoleh kesimpulan sebagai berikut:

1. Kinerja angkutan bus patas AKDP trayek Probolinggo-Malang berdasarkan parameter kinerja diperoleh nilai load factor rata-rata per hari $=0.78$, kecepatan perjalanan rata-rata $=45.66 \mathrm{Km} / \mathrm{jam}$, headway rata-rata diperoleh sebesar 30.30 menit, sedangkan waktu perjalanan ratarata adalah $1.31 \mathrm{menit} / \mathrm{km}$ serta untuk nilai frekwensi armada bus patas adalah 1.98 $\mathrm{kend} / \mathrm{jam}$.

2. Dari hasil analisa keseimbangan supply dan demand bus patas trayek Probolinggo - Malang, kebutuhan armada yang diperlukan sesuai kondisi saat ini adalah 40 armada.

\section{Saran}

Adapun saran yang dapat Penulis berikan adalah sebagai berikut:

1. Sebaiknya perlu diadakan tindak lanjut atau peninjauan kembali terhadap jumlah armada yang berijin trayek saat ini, sehingga pelaksanaan dalam pengoperasiannya lebih optimal.

2. Untuk penelitian yang akan datang diharapkan dapat melakukan penelitian lanjutan dengan mengevaluasi kinerja angkutan umum bus patas berdasarkan tingkat kepuasan terhadap penumpang.

\section{DAFTAR PUSTAKA}

Abbas, Salim H. A. Drs. (1993) Manajemen Transportasi, PT. Raja Grafisindo Persada, Jakarta

Abu Bakar, Iskandar.1995. Menuju Lalu Lintas Dan Angkutan Jalan Yang Tertib. Jakarta : Direktorat Jenderal Perhubungan Darat

Asikin, Muslich Zainal. 2001. Sistem Manajemen Transportasi Kota (Studi Kasus Kota Jogjakarta). Jogjakarta : Philosophy press

Direktorat Jenderal Perhubungan Darat. 1996. Pedoman Teknis Penyelenggaraan Angkutan Penumpang Umum Di Wilayah Perkotaan Dalam Trayek Tetap Dan Teratur. Jakarta

Morlok, K. Edward. 1978. Pengantar Teknik Dan Perencanaan Transportasi. Terjemahan Oleh Ir. Johan Kelanaputra Hainim. 1995. Jakarta : Erlangga

Munawar, Ahmad. 2005. Dasar - Dasar Teknik Transportasi. Yogyakarta : Beta Offset

Nasution, H. M. N. 2004. Manajemen Transportasi. Jakarta : Ghalia Indonesia 
Media Teknik Sipil

Volume 11, Nomor 1, Februari 2013: 1 - 5

Prasetya, Dodiet, \& Romzan Fauzi. 2003.

Studi Evaluasi Kinerja Angkutan Umum Penumpang Di Kota Purwokerto. Skripsi Tidak Diterbitkan : Fakultas Teknik Jurusan Sipil Universitas Muhammadiyah Malang

Tamin, Ofyar. Z. 2000. Perencanaan Dan Permodelan Transportasi. Bandung : Institut Teknologi Bandung

Warpani, Suwardjoko. P. 1990. Merencanakan Sistem Perangkutan. Bandung : Institut Teknologi Bandung

Warpani, Suwadjoko. P. 2002. Pengelolaan Lalu Lintas dan Angkutan Jalan. Bandung : Institut Teknologi Bandung 